\title{
Type I talon cusp on mandibular incisor
}

\author{
Pratik B Kariya, ${ }^{1}$ Rachappa Mallikarjuna, ${ }^{2}$ Bhavna Dave, ${ }^{1}$ Parth B Joshi ${ }^{1}$
}

${ }^{1}$ Department of Pedodontics and Preventive Dentistry, K M Shah Dental College and Hospital, Vadodara, India

${ }^{2}$ Pedodontics and Preventive Dentistry, Child Dental Health, Oman Dental College, Muscat, Oman

\section{Correspondence to \\ Dr Rachappa Mallikarjuna, mmrachappa@gmail.com}

Accepted 4 July 2017
CrossMark

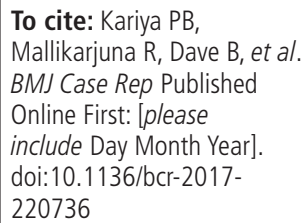

\section{DESCRIPTION}

Talon cusp is a comparably rare developmental dental anomaly assumed to arise because of evagination on the surface of a tooth crown during tooth calcification stage. Talon cusp also called as Eagle's is a well-defined extra cusp like structure located on lingual or palatal surface of deciduous or permanent anterior teeth. Its occurrence may be either unilateral or bilateral, single or multiple teeth in males or females. Prevalence of talon's cusp is reported to be between $0.06 \%$ to $7.7 \%$. Eagle's talon is most commonly seen in maxillary lateral incisor $>$ maxillary central incisor $>$ maxillary canine $>$ mandibular incisor. ${ }^{1}$

Mandibular talon cusp is a rare entity to occur. Mandibular talon cusps are more prevalent in men than women. Occurrence in talon cusp is more common in permanent dentition. Most of the mandibular talon cusp shows unilateral presentation. Talon cusp associated with permanent central incisor and primary lateral incisor are the most common tooth type in mandibular arch. Left sided talon cusp are comparatively more common in mandibular arch. ${ }^{1}$ Mandibular talon cusp may occur in isolation or with other dental anomalies such as hypodontia, hyperdontia, impacted teeth, peg-shaped incisor, dens invaginatus, cleft lip, gemination or fusion.

A 10-year-old boy presented to the clinic with a chief complaint of pain in lower back tooth for 7 days. Intraoral examination showed deep caries in right and left mandibular second deciduous molars. Further, a type I (Hattab classification 1996) talon's cusp was found in relation to mandibular right central incisor (figure 1). ${ }^{2}$ Intraoral periapical radiograph was used for confirmation of talon's cusp. (figure 2). Talon's cusp possesses both aesthetic and functional considerations. The management requires a sufficient knowledge of the

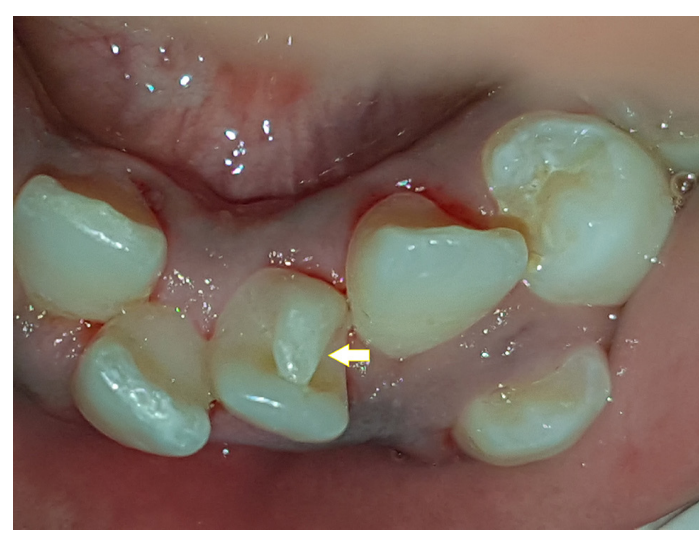

Figure 1 Intraoral photograph showing Eagle's talon in right mandibular central incisor.

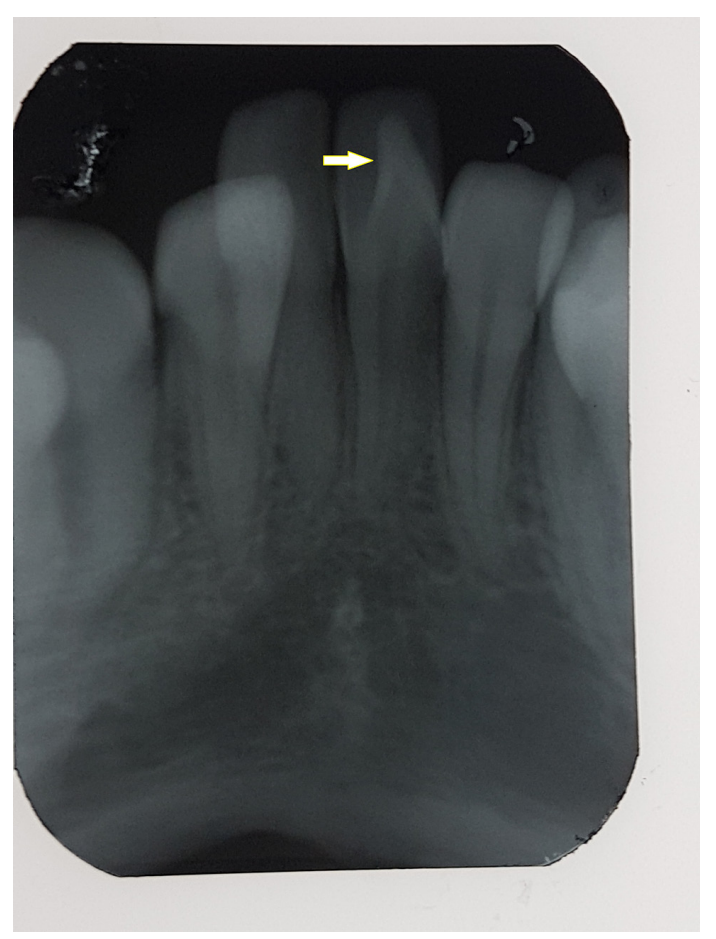

Figure 2 Intraoral periapical radiograph showing Eagle's talon in right mandibular central incisor.

\section{Learning points}

- Early detection of talon's cusp is very important for the appropriate management.

- Correct and preventive treatment plays a very vital role in avoiding the future complications.

present clinical entity and the problems associated with it. Management ranges from no treatment for small cusp, fissure sealant, composite restoration and prophylactic enameloplasty for deep grooves, to calcium hydroxide or Mineral Trioxide Aggregate pulpotomy or root canal therapy for severe cases.

Contributors PBK: case reporting, manuscript preparation, manuscript corrections, acquisition of data, interpretation of data, clinical diagnosis. RM: manuscript preparation and manuscript correction, clinical diagnosis. BD: interpretation of data, manuscript correction. PBJ: case reporting, manuscript preparation, acquisition of data.

Competing interests None declared.

Patient consent Obtained.

Provenance and peer review Not commissioned; externally peer reviewed.

(c) BMJ Publishing Group Ltd (unless otherwise stated in the text of the article) 2017. All rights reserved. No commercial use is permitted unless otherwise expressly granted. 


\section{Images in...}

\section{REFERENCES}

1 Mallineni SK, Panampally GK, Chen Y, et al. Mandibular talon cusps: a systematic review and data analysis. J Clin Exp Dent 2014;6:e408-13.

2 Hattab FN, Yassin OM, al-Nimri KS. Talon cusp in permanent dentition associated with other dental anomalies: review of literature and reports of seven cases. ASDC J Dent Child 1996:63:368-76.

Copyright 2017 BMJ Publishing Group. All rights reserved. For permission to reuse any of this content visit http://group.bmj.com/group/rights-licensing/permissions.

BMJ Case Report Fellows may re-use this article for personal use and teaching without any further permission.

Become a Fellow of BMJ Case Reports today and you can:

- Submit as many cases as you like

- Enjoy fast sympathetic peer review and rapid publication of accepted articles

- Access all the published articles

- Re-use any of the published material for personal use and teaching without further permission

For information on Institutional Fellowships contact consortiasales@bmjgroup.com

Visit casereports.bmj.com for more articles like this and to become a Fellow 